\title{
Pemanfaatan Software Cabri, GeoGebra, dan SketchUp sebagai Media Visualisasi Konsep Matematika pada Materi Geometri Ruang
}

\author{
Devi Eka Wardani Meganingtyas ${ }^{1, \text { a) }}$ \\ ${ }^{1}$ Universitas Negeri Jakarta \\ Email: a) deviekawm@unj.ac.id
}

\begin{abstract}
This research was conducted to determine the advantages of using Cabri, GeoGebra, and SketchUp software as visualization media in the learning process for spatial geometry. In this paper, we use a study literature method by using published scientific journals and references on website. The discussion presented is about the use of Cabri, GeoGebra, and SketchUp software in the learning process on spatial or three-dimensional geometry material. Based on the discussion presented, we can conclude that the three software are capable of helping to visualize three-dimensional shapes so that it can improve students' understanding of the concepts of spatial geometry.
\end{abstract}

Keywords: Software, Cabri, GeoGebra, SketchUp, visualization media, spatial geometry.

\begin{abstract}
Abstrak
Penelitian ini dilakukan untuk mengetahui manfaat dari penggunaan software Cabri, GeoGebra, dan SketchUp sebagai media visualisasi dalam pembelajaran pada materi geometri ruang. Metode yang digunakan dalam penelitian ini adalah studi literatur dengan sumber kajian berupa jurnal ilmiah yang dipublikasikan dan referensi pada website yang diakses melalui internet. Pembahasan yang dipaparkan yakni mengenai penggunaan software Cabri, GeoGebra, dan SketchUp dalam proses pembelajaran pada materi geometri ruang atau dimensi tiga. Berdasarkan pembahasan yang dipaparkan, dapat disimpulkan bahwa ketiga software tersebut dinilai mampu untuk membantu memvisualisasikan bangun dimensi tiga sehingga dapat meningkatkan pemahaman siswa terhadap konsep geometri ruang.
\end{abstract}

Kata kunci: Software, Cabri, GeoGebra, SketchUp, media visualisasi, geometri ruang.

Copyright (c) 2021 Meganingtyas

Corresponding author:

Email Address: deviekawm@unj.ac.id

Received 25 Februari, Accepted 25 Februari 2021, Published 28 Februari 2021 


\section{PENDAHULUAN}

Pembelajaran merupakan suatu rangkaian kegiatan yang meliputi memilih, menetapkan, dan mengembangkan metode untuk mencapai tujuan pembelajaran yang diinginkan. Menurut Hanafy (dalam Pane, 2017), proses pembelajaran ditandai dengan adanya interaksi edukatif yang terjadi yaitu interaksi yang sadar akan tujuan. Interaksi ini berakar dari pihak pendidik (guru) dan kegiatan belajar secara sistematis melalui tahap rancangan, pelaksanaan, dan evaluasi. Pembelajaran tidak terjadi seketika, melainkan berproses melalui tahapan-tahapan tertentu. Dalam pembelajaran, pendidik memfasilitasi peserta didik agar dapat belajar dengan baik. Dengan adanya interaksi tersebut maka akan menghasilkan proses pembelajaran yang efektif sebagaimana yang telah diharapkan.

Pembelajaran matematika di sekolah tidak dapat dipisahkan dari definisi matematika. Menurut Permendikbud Nomor 59 Tahun 2014 (Ramadhanti, 2019), matematika adalah ilmu universal yang berguna bagi kehidupan manusia, mendasari perkembangan teknologi modern berperan dalam berbagai ilmu, dan memajukan daya pikir manusia. Dengan demikian, dapat dikatakan bahwa matematika merupakan ilmu yang penting bagi kehidupan kita yang harus ditanamkan sejak awal pembelajaran di sekolah. Hal ini dikarenakan matematika dapat membantu siswa untuk berpikir secara sistematis, melalui urutan-urutan yang teratur dan tertentu sehingga siswa dapat menyelesaikan persoalanpersoalan yang ditemui dalam kehidupan sehari-hari dengan lebih mudah dan terarah.

Geometri merupakan salah satu cabang ilmu matematika. Geometri merupakan subjek abstrak yang digunakan oleh setiap orang pada kehidupan nyata, seperti: garis, bangun datar, dan bangun ruang. Geometri memiliki peranan penting dalam pondasi dasar yang mendukung penguasaan konsep aljabar, bilangan, aritmetika, serta konsep matematika selanjutnya (Novita et al, dalam Azhar, 2021). Hal ini menjadikan geometri sebagai salah satu topik yang perlu dipelajari dan dikuasai oleh siswa dalam pembelajaran matematika di sekolah.

Salah satu pokok bahasan dalam geometri adalah geometri ruang. Geometri ruang adalah elemen dari geometri yang membahas mengenai bangun ruang, seperti: kubus, balok, dan sebagainya, serta membahas objek abstrak, seperti: titik, garis, dan bidang, objek tersebut didapat dari proses abstrak benda-benda konkret dalam kehidupan nyata (Novita et al, dalam Azhar, 2021). Keabstrakan objek yang dipelajari menyebabkan siswa membutuhkan proses berpikir dengan daya imajinasi pada tingkatan abstrak yang cukup tinggi sehingga masih banyak siswa yang mengalami kesulitan dalam memahami materi geometri ruang yang diajarkan di sekolah dan menyelesaikan permasalahan yang berkaitan dengan geometri ruang. Agar dapat memecahkan permasalahan yang berkaitan dengan geometri ruang, siswa harus memahami konsep dan penalaran dalam keterkaitan materi dan atau rumus yang bersangkutan dengan geometri ruang.

Penelitian yang dilakukan oleh Arvianto (2017) menunjukkan bahwa permasalahan geometri yang paling signifikan adalah pada penentuan jarak dalam bangun ruang, yang dipelajari oleh siswa pada tingkatan kelas XII sesuai dengan Kurikulum 2013. Konsep jarak, seperti: jarak dua titik, jarak titik ke 
garis, jarak garis ke garis, dan yang lainnya, masih belum dipahami siswa dengan baik sehingga siswa belum dapat menyelesaikan soal dengan tepat. Hal ini menyebabkan siswa pada akhirnya mengerjakan soal dengan cara menghafal rumus tanpa memahami konsep dasar tentang jarak dalam geometri ruang.

Berdasarkan penelitian yang dilakukan oleh Arvianto (2017), diperoleh tabel yang mengklasifikasikan kesulitan-kesulitan yang dialami oleh siswa berdasarkan kemampuan akademiknya seperti terlihat pada Tabel 1. Berdasarkan keterangan pada Tabel 1, terlihat bahwa kesulitan-kesulitan yang dialami siswa dalam menyelesaikan soal geometri ruang yang berkaitan dengan konsep jarak antara lain rendahnya pemahaman siswa dalam memahami konsep jarak antara dua titik serta konsep jarak antara titik ke garis, terjadi miskonsepsi dalam diri siswa berkenaan dengan konsep jarak antara dua garis dan jarak antara dua garis yang bersilangan, serta ketidakmampuan siswa dalam membuktikan pernyataan secara langsung.

TABEL 1. Kesulitan yang Dialami Siswa dalam Menyelesaikan Soal Geometri yang Berkaitan dengan Konsep Jarak (Arvianto, 2017)

\begin{tabular}{|c|c|c|}
\hline $\begin{array}{c}\text { Kemampuan Akademik } \\
\text { Tinggi }\end{array}$ & $\begin{array}{c}\text { Kemampuan Akademik } \\
\text { Sedang }\end{array}$ & $\begin{array}{c}\text { Kemampuan Akademik } \\
\text { Rendah }\end{array}$ \\
\hline $\begin{array}{l}\text { 1. Siswa kurang } \\
\text { memahami konsep jarak } \\
\text { antara dua titik serta } \\
\text { konsep jarak antara titik } \\
\text { ke garis. }\end{array}$ & 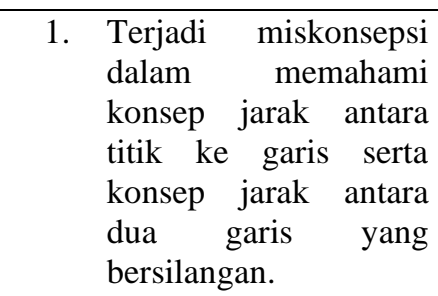 & $\begin{array}{l}\text { Terjadi miskonsepsi } \\
\text { dalam memahami } \\
\text { konsep jarak antara titik } \\
\text { ke garis serta konsep } \\
\text { jarak antara dua garis } \\
\text { yang bersilangan. }\end{array}$ \\
\hline $\begin{array}{lr}\text { 2. Terjadi } & \text { miskonsepsi } \\
\text { dalam diri } & \text { siswa } \\
\text { berkenaan } & \text { dengan } \\
\text { konsep jarak } & \text { antara dua } \\
\text { garis, } & \text { sehingga } \\
\text { berakibat } & \text { pada } \\
\text { kesalahan } & \text { dalam } \\
\text { penggunaan } & \text { rumus } \\
\text { yang } & \text { merupakan } \\
\text { implikasi } & \text { dari } \\
\text { keterkaitan } & \\
\text { antarkonsep. } & \end{array}$ & $\begin{array}{lr}\text { 2. Terjadi } & \text { miskonsepsi } \\
\text { dalam diri } & \text { siswa } \\
\text { berkenaan } & \text { dengan } \\
\text { konsep jarak } & \text { antara dua } \\
\text { garis, } & \text { sehingga } \\
\text { berakibat } & \text { pada } \\
\text { kesalahan } & \text { dalam } \\
\text { penggunaan } & \text { rumus } \\
\text { yang } & \text { merupakan } \\
\text { implikasi } & \text { dari } \\
\text { keterkaitan } & \\
\text { antarkonsep. } & \end{array}$ & 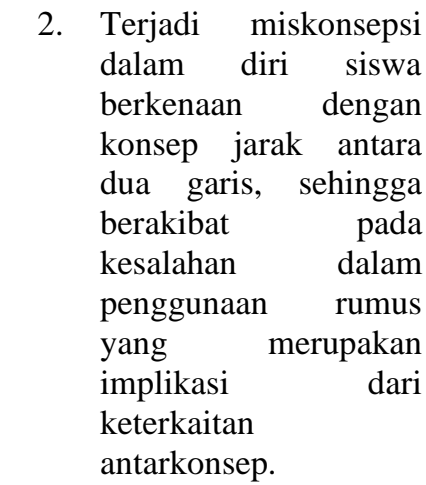 \\
\hline & $\begin{array}{l}\text { 3. Siswa belum dapat } \\
\text { membuktikan } \\
\text { pernyataan } \\
\text { langsung }\end{array}$ & $\begin{array}{l}\text { 3. Siswa belum dapat } \\
\text { membuktikan } \\
\text { pernyataan } \\
\text { langsung }\end{array}$ \\
\hline
\end{tabular}

Sejalan dengan hal tersebut, terdapat penelitian meta analisis yang dilakukan oleh Wardhani (2019) dengan judul "Geometri dan Permasalahannya dalam Pembelajaran Matematika di Sekolah". Penelitian tersebut mengkaji beberapa penelitian sebelumnya terkait dengan permasalahan dalam pembelajaran geometri. Hasil analisisnya menghasilkan beberapa bidang permasalahan yang dirangkum dalam bentuk tabel, yakni permasalahan persepsi, permasalahan pada penggunaan prosedur, konsep, dan prinsip, miskonsepsi terhadap proses dan kegiatan visual, permasalahan penggunaan deduktif aksiomatik, dan lemahnya koneksi dan penalaran dalam geometri. 
Rizkiana MS, dkk. (2019) juga melakukan penelitian tentang kemampuan visual spasial siswa dalam menyelesaikan soal bangun ruang kubus dan balok. Kemampuan visual spasial adalah kemampuan yang melibatkan daya imajinasi dan daya ruang yang tinggi. Subjek penelitian ini adalah 5 siswa SMP kelas VIII dengan teknik pengambilan purposive sampling. Hasil yang didapat dalam penelitian tersebut diantaranya subjek tidak dapat mengonstruksi dan merepresentasikan model-model bangun ruang dengan benar, khususnya menggambar letak diagonal ruang. Hal ini dikarenakan subjek penelitian masih belum memahami perbedaan antara diagonal bidang dan diagonal ruang. Selain itu, subjek tidak dapat membenarkan suatu pernyataan yang berasal dari gambar yang dibuat sendiri.

Penelitian tentang kesalahan siswa dalam menyelesaikan soal kemampuan spasial matematis juga dilakukan oleh Utami (2020), dimana subjek penelitiannya adalah 30 siswa kelas X di Madrasah Aliyah Swasta di Singkawang, Kalimantan Barat. Kemampuan spasial matematis merupakan kemampuan yang berfokus pada bidang geometri. Hasil analisis data yang diperoleh menunjukkan bahwa terdapat dua bentuk kesalahan yang dilakukan oleh siswa dalam menyelesaikan soal kemampuan spasial matematis, yakni kesalahan konsep dan kesalahan operasi/prosedur. Kesalahan konsep yang dilakukan oleh siswa diantaranya adalah kesalahan dalam menggambar, menentukan posisi gambar, dan ketidakpahaman maksud soal sehingga tidak dapat membuat gambar. Adapun kesalahan operasi yang dilakukan oleh siswa yakni siswa dapat memahami konsep atau menggunakan rumus yang tepat namun melakukan beberapa kekeliruan dalam proses perhitungan dan pengerjaan yang disebabkan oleh kurangnya ketelitian dalam pengerjaan soal.

Pada tahun 2021, penelitian serupa juga dilakukan oleh Azhar dan Senjayawati. Penelitian tersebut menganalisis kesalahan siswa SMK dalam menyelesaikan soal materi geometri ruang. Ada empat butir soal yang diberikan kepada siswa, yakni menentukan kedudukan titik, menghitung besar sudut, menghitung jarak antara bidang ke bidang, dan menghitung jarak antara garis ke garis. Kesalahan yang paling banyak dialami oleh siswa adalah menghitung jarak antara garis ke garis. Hasil dari penelitian tersebut mengungkapkan bahwa ada tiga jenis kesalahan yang dilakukan oleh siswa, yakni kesalahan teknik, kesalahan konsep, dan kesalahan prosedural. Kesalahan teknik disebabkan oleh ketidaktelitian siswa ada saat melakukan perhitungan, kesalahan konsep disebabkan oleh ketidakmampuan siswa dalam memahami maksud dari permasalahan yang diberikan, sedangkan kesalahan prosedural disebabkan oleh ketidaktelitian siswa dalam menyelesaikan permasalahan sehingga ada langkah perhitungan yang terlewat oleh pengerjaan siswa.

Hasil-hasil penelitian yang dijelaskan sebelumnya mengungkap bahwa geometri ruang merupakan salah satu materi dalam ilmu matematika yang membutuhkan pendalaman konsep dasar, salah satu caranya adalah dengan cara memvisualisasikan bangun geometri yang dipelajari sehingga dapat memudahkan siswa dalam mempelajari geometri ruang, khususnya sub pokok bahasan jarak. Terlebih pada masa pandemi COVID-19 ini, pembelajaran di sekolah dilakukan secara daring (dalam jaringan) sehingga guru harus benar-benar mampu memvisualisasikan konsep geometri ruang kepada siswasiswanya karena tidak dapat bertatap muka secara langsung. Hal ini juga menjadi tantangan tersendiri 
bagi guru agar dapat memahamkan konsep geometri ruang dengan benar kepada siswanya.

Salah satu cara yang dapat digunakan untuk mengatasi hasil tersebut adalah adalah dengan menggunakan media pembelajaran untuk membantu siswa dalam mempelajari materi geometri ruang. Media pembelajaran yang dimaksud dapat berupa produk hasil karya mandiri atau dengan menggunakan software atau aplikasi tertentu yang dapat membantu proses pembelajaran. Ada beberapa macam software yang dapat digunakan oleh guru untuk membantu siswa dalam memvisualisasikan konsep geometri ruang. Pada penelitian ini akan dibahas tentang pemanfaatan software yang dapat digunakan untuk memberikan pemahaman konsep matematis kepada siswa untuk materi geometri.

\section{METODE}

Metode yang digunakan dalam penelitian ini adalah studi literatur atau literature review yang berfokus pada hasil penulisan yang berkaitan dengan topik penulisan. Metode studi literatur adalah serangkaian kegiatan yang berkenaan dengan metode pengumpulan data pustaka, membaca dan mencatat, serta mengelola bahan penulisan. Sumber kajian yang digunakan berupa jurnal ilmiah yang dipublikasikan dan referensi pada website yang diakses melalui internet.

\section{HASIL DAN PEMBAHASAN}

Berdasarkan hasil penelitian-penelitian yang dibahas sebelumnya, dapat dilihat bahwa masih banyak kesalahan yang dilakukan oleh siswa dalam menyelesaikan permasalahan terkait materi geometri, khususnya geometri ruang. Penyebab kesalahan yang dialami oleh siswa tersebut salah satunya adalah kurangnya kemampuan siswa dalam memvisualisasikan konsep materi geometri ruang.

Penanaman konsep materi geometri ruang berhubungan erat dengan kemampuan memvisualisasikan unsur-unsur bangun ruang dan hubungan antar unsur-unsur tersebut yang kemudian akan dibawa kembali ke dalam simbol-simbol yang lebih abstrak. Menurut Van Hiele (Abdussakir, dalam Tyaningsih, 2015), tahap awal pembelajaran geometri adalah tahap pengenalan (visualisasi), siswa mulai belajar mengenai suatu bentuk geometri secara keseluruhan untuk kemudian menjadi konsep dasar untuk mengantarkannya kepada tingkat berpikir yang lebih tinggi. Misalnya, pada proses pembelajaran siswa diperlihatkan berbagai gambaran (visualisasi) tentang konsep garis dalam bangun ruang. Kemudian sebagai umpan balik, siswa dapat memberikan tafsiran dan visualisasi kembali sesuai dengan konsep yang ditangkap dan kreativitasnya. Pada akhirnya, siswa diharapkan mampu memahami konsep yang lebih abstrak.

Untuk dapat membantu siswa dalam memvisualisasikan konsep geometri ruang, diperlukan media pembelajaran yang dapat digunakan oleh guru dan siswa dengan harapan agar penanaman konsep geometri ruang kepada siswa dapat dilakukan dengan tepat dan baik. Salah satu contoh media pembelajaran yang digunakan adalah dengan memanfaatkan software tersedia di internet. Pada pembahasan ini akan dijelaskan tentang pemanfaatan beberapa macam software dalam memvisualisasikan konsep matematika pada materi geometri ruang yang diperoleh dari hasil penelitian- 
penelitian sebelumnya.

\section{Penggunaan Software Cabri dalam Pembelajaran Materi Geometri Ruang}

Penanaman konsep geometri, khususnya geometri ruang, tidaklah mudah. Hal ini dikarenakan bahan kajiannya yang bersifat abstrak sehingga tidak dapat langsung diserap oleh siswa. Para guru memerlukan strategi khusus untuk menanamkan konsep geometri ruang kepada siswa, salah satunya adalah dengan menggunakan software atau aplikasi yang dapat memudahkan siswa dalam memvisualisikan konsep geometri ruang.

Supriyono, dkk (2012) dalam penelitiannya mengembangkan bahan ajar dimensi tiga berbasis Cabri di Sekolah Menengah Atas (SMA). Cabri merupakan suatu program aplikasi yang dapat digunakan sebagai media pembelajaran untuk menanamkan konsep-konsep matematika terutama konsep-konsep geometri. Cabri dalam pembelajaran geometri dapat dipergunakan untuk membangun, melihat, dan memanipulasi berbagai macam objek dimensi tiga secara interaksi. Cabri juga dapat digunakan untuk mengukur panjang, menghitung jarak, menghitung besar sudut, menghitung volume dan bahkan dapat memainkan ulang (replay) proses bagaimana kita membangun suatu objek dimensi tiga (Sophie and P. R. de Cotret, dalam Supriyono, 2012).

Berdasarkan penelitian yang dilakukan tersebut, dihasilkan suatu bahan ajar matematika, yakni bahan ajar dimensi tiga dengan menggunakan media Cabri yang valid dan praktis. Hal ini dikarenakan hasil penilaian para evaluator menyatakan bahwa bahan ajar yang dikembangkan dinilai baik sekali berdasarkan kriteria konten (kelayakan isi), kebahasaan, konstruk (sajian), dan kegrafisan, serta hasil penilaian peserta didik juga memberikan penilaian yang baik sekali terhadap visualisasi media dari bahan ajar. Selain itu, hasil uji coba dalam pembelajaran dan komentar yang didapat dari peserta didik menunjukkan kemudahan peserta didik dalam menggunakan bahan ajar dan media Cabri, serta kemudahan yang dialami oleh peserta didik dalam memahami materi bahan ajar.

\section{Penggunaan Software GeoGebra dalam Pembelajaran Materi Geometri Ruang}

Software GeoGebra merupakan software yang memuat geometri dan aljabar serta menjadi salah satu software yang banyak digunakan dalam pembelajaran matematika karena dapat memvisualisasikan objek-objek geometri. Pada tahun 2017, Machromah (2019) memberikan pelatihan kepada guru-guru menggunakan software GeoGebra. Pelatihan yang diselenggarakan bertujuan untuk mengenalkan software GeoGebra dan memberikan pelatihan penggunaannya terutama pada materi dimensi tiga.

Pada awal kegiatan, peserta diperkenalkan dengan tampilan 3D Graphics pada software GeoGebra dan menu-menu yang ada pada tampilan tersebut. Selanjutnya, peserta diajarkan cara membuat bangun ruang tiga dimensi dan membuat jaring-jaring yang secara otomatis dapat membuka dan menutup kembali dari suatu bangun. Setelah itu, peserta diajarkan cara menentukan jarak titik ke bidang. Pelatihan ini mendapatkan respon yang positif dari peserta.

Penelitian menggunakan software GeoGebra juga dilakukan oleh Pamungkas, dkk. (2020) yang dituangkan dalam artikelnya yang berjudul "Geogebra Implementation to Improve Understanding of 
Spatial Geometry Concepts”. Pada penelitiannya, Pamungkas, dkk. Menggunakan dua kelompok, kelompok pertama sebagai kelas eksperimen yang memperoleh perlakuan berupa penggunaan GeoGebra dan kelompok kedua sebagai kelas kontrol yang memperoleh perlakuan berupa pembelajaran konvensional. Subjek penelitian ini adalah mahasiswa semester II Program Studi Pendidikan Matematika Universitas Tidar pada perkuliahan geometri ruang.

Hasil penelitian menunjukkan bahwa setelah siswa menggunakan GeoGebra untuk membantu pembelajarannya, terdapat peningkatan kemampuan dalam memahami konsep geometri ruang. Hasil lain yang diperoleh adalah adanya peningkatan kemampuan pemahaman konsep geometri ruang pada kedua kelompok siswa setelah diberikan pembelajaran atau perlakuan. Hal ini menunjukkan bahwa penggunaan software Geogebra dapat digunakan sebagai media visualisasi yang mampu meningkatkan pemahaman siswa terhadap konsep matematis pada materi bangun ruang.

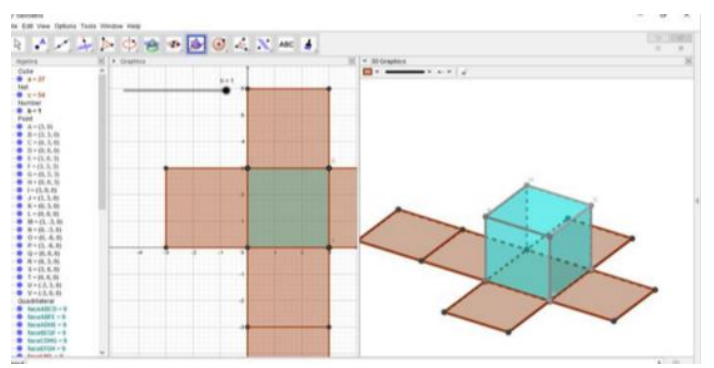

Gambar 1. Tampilan jaring-jaring kubus (Machromah, 2019)

\section{Penggunaan Software SketchUp dalam Pembelajaran Materi Geometri Ruang}

SketchUp, atau dikenal juga dengan sebutan Google SketchUp, dikembangkan oleh Startup Company, Colorado pada tahun 1999 oleh Brad Schell. Pada awalnya, SketchUp digunakan sebagai alat untuk menciptakan konten tiga dimensi yang memungkinkan para profesional desain untuk membuat objek tiga dimensi dengan mudah. Hal ini dikarenakan SketchUp mudah digunakan, memberi visualisasi yang baik tentang objek dimensi tiga, objek dimensi tiga yang dibuat dapat diputar sehingga memudahkan untuk mengamati objeknya, serta terdapat berbagai macam tool yang dapat digunakan untuk menciptakan objek dimensi tiga (Nasution dan Sa'dijah, 2015).

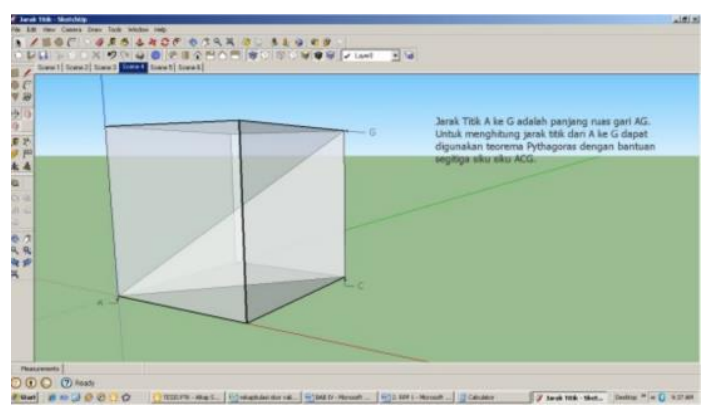

Gambar 2. Visualisasi jarak antartitik menggunakan SketchUp (Nasution dan Sa'dijah, 2015) 
Pada tahun 2012, Nasution dan Sa'dijah (2015) melakukan penelitian untuk memahamkan konsep jarak pada topik dimensi tiga kelas $\mathrm{X}$ menggunakan pembelajaran langsung berbantuan Google SketchUp. Subjek penelitian ini adalah 39 siswa kelas X di SMA Negeri 1 Turen. Penelitian ini dilakukan melalui dua siklus, dimana Siklus I dilakukan pada Pertemuan ke-1 dan ke-2, dan Siklus II dilakukan pada Pertemuan ke-3, ke-4, dan ke-4.

Berdasarkan penelitian tersebut, diperoleh hasil bahwa penggunaan SketchUp dapat meningkatkan pemahaman siswa tentang jarak pada dimensi tiga dan dapat meningkatkan ketuntasan klasikal. Berdasarkan hasil wawancara yang dilakukan juga diperoleh informasi bahwa SketchUp dapat membantu pembelajaran yang dilakukan oleh guru sehingga siswa dapat memahami konsep jarak pada dimensi tiga. Selain itu, visualisasi objek tiga dimensi pada SketchUp sangat membantu siswa dan membuat siswa terpacu untuk mengungkapkan ide atau gagasan.

Selanjutnya, Sekarwulan (2019) juga melakukan penelitian menggunakan SketchUp pada pembelajaran dimensi tiga. Hal ini bertujuan untuk meningkatkan kemampuan spatial sense pada subjek penelitian. Adapun yang menjadi subjek penelitian adalah siswa kelas XII IPA SMAN 1 Kota Sukabumi. Latar belakang dari penelitian ini adalah masih banyak siswa yang tidak bisa memvisualisasikan bangun dimensi tiga yang digambar oleh guru di papan tulis sehingga diperlukan media pembelajaran yang dapat membantu siswa dalam memvisualisasikan bangun dimensi tiga tersebut. Penggunaan SketchUp dipilih karena didesain dengan sangat familiar dan mudah digunakan oleh siapapun tanpa harus menguasai teknik-teknik yang rumit.

Penelitian dilakukan sebanyak 4 siklus dimana masing-masing siklus terdiri dari 2 pertemuan. Hasil dari penelitian tersebut antara lain penggunaan SketchUp membuat suasana di kelas menjadi berbeda karena siswa menjadi lebih tertarik dan termotivasi untuk belajar. Hal ini dikarenakan penggunaan SketchUp dapat membantu siswa dalam memvisualisasikan bangun ruang menjadi mirip dengan aslinya dan dapat diputar-putar sesuai kebutuhan sehingga dapat dilihat dari berbagai sudut. Penggunaan SketchUp dengan pendekatan Problem Based Learning (PBL) juga dinilai sangat efektif karena siswa dapat belajar secara bermakna dan melatih kemampuan spatial sense siswa dengan lebih optimal. Dengan dikuasainya konsep secara lebih mendalam maka siswa akan lebih mudah memahami materi pembelajaran yang selanjutnya.

\section{KESIMPULAN}

Berdasarkan paparan pada hasil dan pembahasan, dapat disimpulkan bahwa penggunaan software dapat membantu siswa dalam memvisualisasikan konsep matematika pada materi bangun ruang. Beberapa software yang dapat digunakan adalah Cabri, GeoGebra, dan SketchUp. Software-software tersebut dapat memvisualisasikan objek tiga dimensi sehingga dinilai mampu untuk meningkatkan pemahaman siswa terhadap konsep geometri ruang dan menjadikannya sebagai media pembelajaran yang digemari oleh siswa serta membuat siswa lebih tertarik dan termotivasi untuk belajar. 


\section{REFERENSI}

Arvianto, I. R. (2017). Analisis Kesulitan Siswa SMA dalam Menyelesaikan Soal Geometri yang berkaitan dengan Jarak. Ekuivalen, 26(2), 95-100.

Azhar, W. S., \& Senjayawati, Eka (2021). Analisis Kesalahan Siswa SMK dalam Menyelesaikan Soal Materi Geometri Ruang. Jurnal Pembelajaran Matematika Inovatif, 4(1), 185-192.

Machromah, I. U. (2019). GeoGebra sebagai Media Visualisasi Konsep Matematika Dimensi 3. The $9^{\text {th }}$ University Research Colloqium 2019 Universitas Muhammadiyah Purworejo, 197-204.

Nasution, A. H., \& Sa'dijah, Cholis (2015). Pemahaman Konsep Jarak pada Topik Dimensi Tiga Kelas X Menggunakan Model Pembelajaran Langsung Berbantuan Google SketchUp. Jurnal KIP, III(3), 624-632.

Pamungkas, M. G., dkk. (2020). Geogebra Implementation to Improve Understanding of Spatial Geometry Concepts. Alauddin Journal of Mathematics Education, 2(2), 107-116.

Pane, A., \& Dasopang, M. D. (2017). Belajar dan Pembelajaran. FITRAH Jurnal Kajian Ilmuilmu Keislaman, 03(2), 333-352.

Ramadhanti, Eva, \& Marlina, Rina (2019). Pembelajaran Realistic Mathematics Education (RME) terhadap Kemampuan Pemahaman Matematis. Prosiding Seminar Nasional Matematika dan Pendidikan Matematika Sesiomadika 2019, 876-882.

Rizkiana MS., S., dkk. (2019). Kemampuan Visual Spasial Siswa dalam Menyelesaikan Soal Bangun Ruang Kubus dan Balok. Prosiding Seminar Nasional MIPA UNIBA 2019, 99-106.

Sekarwulan, A. R. (2019). Penggunaan Media 3D SketchUp pada Pembelajaran Dimensi Tiga untuk Meningkatkan Kemampuan Spatial Sense pada Siswa Kelas XII IPA SMAN 1 Sukabumi. JURNAL PENDIDIKAN: Riset dan Konseptual, 3(2), 143-149.

Supriyono, A., dkk. (2012). Pengembangan Bahan Ajar Dimensi Tiga Berbasis Cabri di Sekolah Menengah Atas. Jurnal Pendidikan Matematika, 6(2), 1-18.

Tyaningsih, R. Y. (2015). Pengembangan Media Pembelajaran Berbantuan Komputer pada Materi Geometri Ruang Berbasis Van Hiele Levels untuk Siswa SMA Kelas X Semester 2. Jurnal Math Educator Nusantara, 01(02), 171-186.

Utami, Citra (2020). Kesalahan Siswa dalam Menyelesaikan Soal Kemampuan Spasial Matematis. Al-Khwarizmi: Jurnal Pendidikan Matematika dan Ilmu Pengetahuan Alam, $8(2), 123-132$.

Wardhani, I. S. (2019). Geometri dan Permasalahannya dalam Pembelajaran Matematika di Sekolah (Suatu Penelitian Meta Analisis). Prosiding Seminar Nasional Integrasi Matematika dan Nilai Islami, 3(1), 124-129. 